Journal of Applied Biology \& Biotechnology Vol. 7(01), pp 029-034, January-February, 2019

Available online at http://www.jabonline.in

DOI: $10.7324 / \mathrm{JABB} .2019 .70106$

(cc) BY-NC-SA

\title{
Purification and characterization of tannase from the local isolate of Aspergillus niger
}

\author{
Saja Taha Yaseen Al-Mraai, Dhia Falih Al-Fekaiki, Alaa Jabbar Abd Al-Manhel* \\ Department of Food Sciences, College of Agriculture, University of Basrah, Basrah City, Iraq.
}

\begin{tabular}{|c|c|}
\hline ARTICLE INFO & ABSTRACT \\
\hline $\begin{array}{l}\text { Article history: } \\
\text { Received on: May 01, } 2018 \\
\text { Accepted on: May 29, } 2018 \\
\text { Available online: January 20, } 2019\end{array}$ & $\begin{array}{l}\text { Fungi of genus Aspergillus are active producers of extracellular tannase, and characteristics of enzyme production } \\
\text { by local Aspergillus species have been well studied. The aim of this experimental study is isolation and partial } \\
\text { purification of tannase enzyme from the Aspergillus niger fungus species. The purification was achieved by } \\
\text { applying respectively ammonium sulfate ( } 50-70 \% \text { ), dialysis with a specific activity } 1227.08 \text { (unit/mg protein), } \\
\text { then passed the enzymatic extract through superdex } 200 \text { column in the gel filtration chromatography by using }\end{array}$ \\
\hline $\begin{array}{l}\text { Key words: Fungi, Aspergillus } \\
\text { niger, Tannase, Purification, } \\
\text { Characterization. }\end{array}$ & $\begin{array}{l}\text { AKTA Pure } 25 \text { apparatus, the activity and the specific activity reached to } 525.12 \text { (unit } / \mathrm{ml} \text { ) and } 2917.33 \text { (unit } / \mathrm{mg} \\
\text { protein) respectively, with purification fold of } 11.629 \text { and yield } 18.40 \% \text {. One peak was obtained from an enzyme } \\
\text { purity, which diagnosed by the absence of denaturation substances for protein SDS. Characteristics of pure } \\
\text { enzyme showed that the molecular weight of the pure enzyme was determined, and it was found that the weight } \\
\text { of enzyme was } 95.49 \mathrm{KDa} \text { by using sodium dodecyl sulfate (SDS) polyacrylamide gel electrophoresis, the } \\
\text { enzyme was active in pH range } 3 \text { to } 6 \text { and temperature of } 20 \text { to } 50^{\circ} \mathrm{C} \text {. The optimum pH and the temperature for } \\
\text { tannase activity were recorded to be } \mathrm{pH} 5 \text { and } 35^{\circ} \mathrm{C} \text {, respectively. Moreover, the tannase activity was inhibited } \\
\text { by } \mathrm{Cu}, \mathrm{Fe} \text { and } \mathrm{Hg} \text { ions while increased by } \mathrm{Mg} \text { and } \mathrm{K} \text { ions when added at } 1 \text { and } 5 \mathrm{mM} \text {. }\end{array}$ \\
\hline
\end{tabular}

\section{INTRODUCTION}

Tannase or tannin acyl hydrolase (E.C: 3.1.1.20) is an enzyme works on the hydrolysis of tannic acid through breaking the ester and side bonds to its primary units of glucose and gallic acid. The enzyme is important industrially and has several applications in various industries such as food, animal feed, cosmetics, pharmaceutical, chemical, and leather industries [1]. Many foods contain a high level of tannin including tea, coffee, plenty of spices and some types of fruit and vegetables like grapes, apricots, dates, pomegranates strawberries, eggplant as well as nuts, such as peanuts and nuts [2]. Studies have shown that the tannin is responsible for reducing the amount of intaking food, in other mean an anti-nutrition factors, as a result of lowering the food efficiency and the net energy of metabolism and reduce the digestive protein because of its effect on the digestive enzyme, then lowering digestion of an amino acids as well as preventing degradation of the starch inside alimentary canal and cause damage to the cells lining the stomach and thus influence in the degree of absorption of the rest food elements and its ability on the linkage with the protein to form complex protein-

${ }^{*}$ Corresponding Author

Alaa Jabbar Abd Al-Manhel, Department of Food Sciences, College of

Agriculture, University of Basrah, Basrah City, Iraq.

E-mail:alaafood_13@yahoo.com tannin or precipitate in the form of a gel in water solutions, so the foods which have a high levels of tannin regard a low nutritional value food, as well as tannin, has a negative impact on the iron absorption being associated with iron in the digestive system thereby reducing of its vital provided and absorption $[3,4,5]$. The current study aims to purification and characterization of tannase produced from a local fungal isolate for the purpose of using its in clarification of juices and reduce the content of tannin then removing the bitterness in beverages, juices, and tea, also the gallic acid producing from degradation by added tannase has an importance like antioxidant and antimicrobial activity which is more positive on the quality of the juices.

\section{MATERIALS AND METHODS}

\subsection{Isolation, Production, and Extraction}

Forty fungal isolates of molds were locally isolated from soil and tea waste then isolates molds were diagnosed at Biotechnology lab. Of Agriculture College-University of Basrah-Iraq, Aspergillus niger was selected as potential extracellular tannase depending on the phenotypic and microscopic characteristics of colonies accordance with the taxonomy keys that mentioned in [6,7]. Wheat Bran moistens with the pomegranate peel extract $(1: 2)$ was used for tannase production and enzyme extracted with acetate buffer $(50 \mathrm{ml} / 10 \mathrm{~g}, \mathrm{pH} 5,0.2 \mathrm{M})$ at 200 rpm for $1 \mathrm{hr}[8]$. 


\subsection{Purification of Enzyme}

\subsubsection{Concentration by Ammonium Sulfate}

Crystals of ammonium sulfate were added to the crude extracted gradually for the concentration of the enzyme with stirring continuously for 4 hours until solubilization with saturation ratio between $20-80 \%$. Centrifugation at $10000 \mathrm{rpm}$ for $15 \mathrm{~min}$. at $4^{\circ} \mathrm{C}$. In each step estimated the enzymatic activity and concentration of protein in the filtrate and precipitate [9].

\subsubsection{Enzyme Assay}

Enzymatic activity was estimated according to [10]. One unit of tannase activity was defended as the amount of enzyme that hydrolyzed 1 Microgram of tannic acid in 1 minute under the assay condition, The specific activity of an enzyme is calculated by dividing the enzyme activity on protein concentration.

\subsubsection{Protein Assay}

A concentration of protein was measured according to [11].

\subsubsection{Gel Filtration}

The process of gel filtration was done by using ÄKTA Pure 25 apparatus with Superdex 200 10/300 GL column (10 mm diameter, column size $23.562 \mathrm{ml}$, pressure $1.5 \mathrm{mpa}$, dimensions $10 \times 300 \mathrm{~mm}$, flow rate of $0.5 \mathrm{ml} / \mathrm{min}$ ) filled packaged with agarose and dextran, the column was calibrated with acetate buffer $\mathrm{pH} 5$ (4 liters), then injecting the concentrated sample $(0.5 \mathrm{ml})$ which was obtained from the precipitation of ammonium sulphate in the column gradually after filtered by millipore filter $0.22 \mu \mathrm{m}$ and following the separated peaks on the wavelength of $280 \mathrm{~nm}$, then measured the enzymatic activity (unit/ml).

\subsubsection{Electrophoresis}

The purification of an enzyme was estimated by using a polyacrylamide gel electrophoresis with an absence of the denaturation substances sodium dodecyl sulfate (SDS).

\subsection{Characterization of the Purified Enzyme}

\subsubsection{Determination of molecular weight of enzyme}

Polyacrylamide gel electrophoresis with a presence of SDS was performed according to the method of [12] modified by [13] using the slab electrophoresis apparatus. The molecular weight was determined from the relative mobility (calculated by measuring the amount of movement of the protein and dividing that by the distance of the movement dye (bromophenol blue) from the origin) of the standard protein such as glucose oxidase $(160 \mathrm{KDa})$, bovine serum albumin (67 KDa), papain (45 KDa), pepsin (34 KDa) and lysozyme (14.4) KDa.

\subsubsection{Optimum pH for Enzyme Activity and Stability}

Sodium acetate buffer of $\mathrm{pH}$ ranges from (3-5.5) and phosphate buffer of $\mathrm{pH}$ ranges from (6-8) with a concentration of $0.2 \mathrm{M}$ were used to calculate the optimum $\mathrm{pH}$ for enzymatic activity (unit/ml), while the optimum $\mathrm{pH}$ for stability was examined as remaining activity (\%) using different buffer solutions of $\mathrm{pH}$ ranges between (3-9) at $30^{\circ} \mathrm{C}$ for $2 \mathrm{~h}$ using the tannin as a substrate.

\subsubsection{Optimum Temperature for Enzyme Activity and Stability}

The enzyme was incubated in a water bath to estimation the optimum temperatures with a range between $(20-80)^{\circ} \mathrm{C}$ for $30 \mathrm{~min}$., where the optimum temperature for stability was estimated after incubation tannase in a water bath at temperatures ranged from $(20-80)^{\circ} \mathrm{C}$ for $1 \mathrm{~h}$, then cooling directly in an ice bath.

\subsubsection{Effect of metal ions on enzyme activity}

Equal volumes of purified enzyme were mixed with 1 and 5 $\mathrm{mM}$ of metal salt $\left(\mathrm{MgCl}_{2}, \mathrm{HgCl}_{2}, \mathrm{FeSO}_{4}, \mathrm{ZnSO}_{4} .7 \mathrm{H}_{2} \mathrm{O}, \mathrm{KCl}\right.$, $\mathrm{CuCl}_{2} .2 \mathrm{H}_{2} \mathrm{O},(\mathrm{NH} 4){ }_{2} \mathrm{SO}_{4}, \mathrm{CaCl}_{2}$ ) then incubated at $30^{\circ} \mathrm{C}$ for 60 min after that enzyme activity was assayed and remaining activity was calculated.

\section{RESULTS AND DISCUSSION}

\subsection{Isolation}

40 Pure isolation isolated from different sources as soil belongs to 7 genes, it was observed the superiority of Aspergillus niger in the production of tannase. Noticing [14] when isolating 35 molds isolation near from desert plants that $64.57 \%$ isolates were produced tannase, while [15] was able to isolate 16 molds isolation producing for tannase from different parts of plants.

\subsection{Purification}

The specific activity was increasing gradually until reaching to 1227.08 (unit $/ \mathrm{mg}$ ) at saturation of $50-70 \%$ with purification fold of 4.891 and yield $50.821 \%$ as shown in Table 1 . The obtained results agreed with many of the studies that pointed to the importance of the use of ammonium sulfate as the first step of tannase purification [16] was used of ammonium sulfate at saturation rate $70 \%$ to concentration of the enzyme with a specific activity 4.58 (unit $/ \mathrm{mg}$ ) with purification fold of 1.91 and yield $68.75 \%$, while [17] were showed the possibility of enzyme precipitation by ammonium sulfate with saturation $75 \%$ from Aspergillus niger with enzymatic yield $72.5 \%$ and purification fold of 1.4 .

Table 1: Purification of tannase from Aspergillus niger.

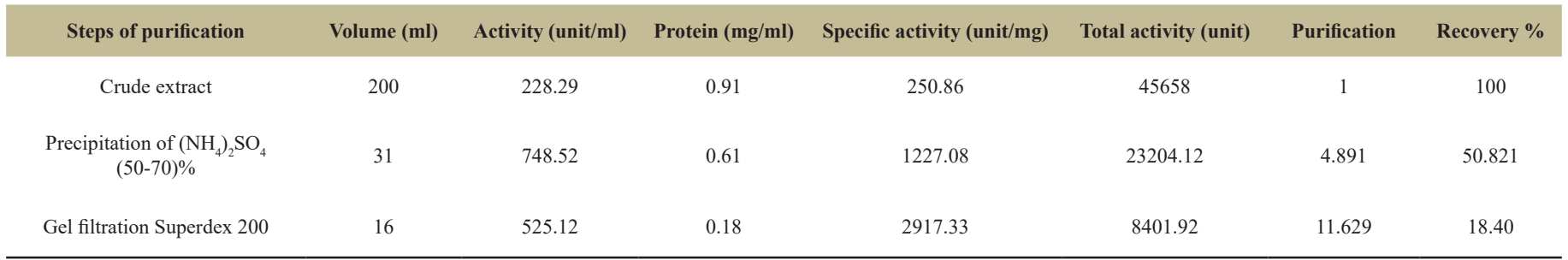




\subsection{Gel Filtration}

The results shown in Figure 1 an existence of a two peaks of the enzymatic extract after precipitation by ammonium sulphate and measured the activity of protein on the wavelength of $280 \mathrm{~nm}$, where appeared a high enzymatic activity in the first peak 525.12 (unit $/ \mathrm{ml})$, which was chosen to complete the study with enzymatic yield $18.40 \%$ and purification fold of 11.629. The obtained results were similar to what many researchers have found where in made [18] a purification of the enzyme with a gel filtration technique using sephadex G-200 with a number of purification fold of 12.25 which produced from a fungus Mucor spp. also, the results agreed with [16] when studying enzyme purification of Aspergillus niger which purified by gel filtration technique using sephadex G-75 with an enzymatic yield $24 \%$ and purification fold of 2.5 .

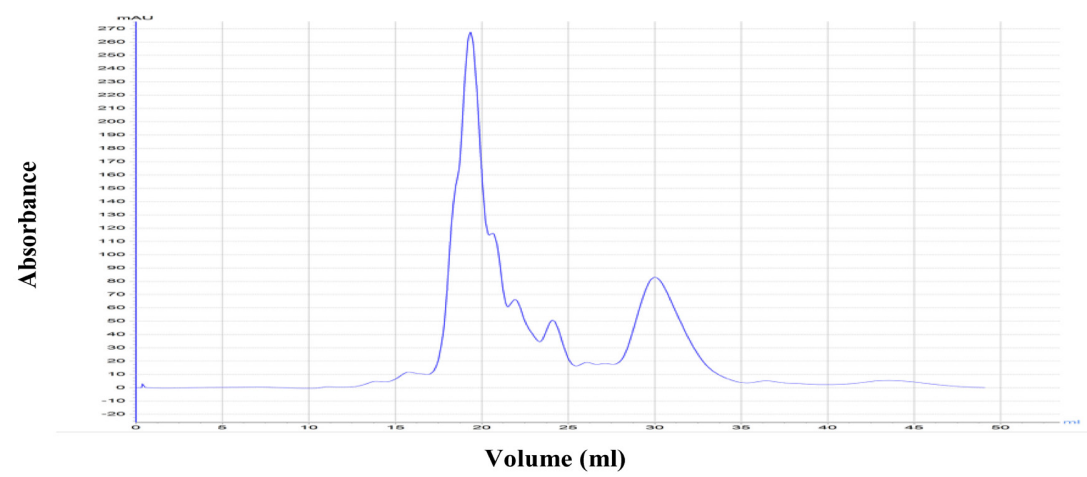

Figure 1: Chromatogram of gel filtration for tannase enzyme by ÄKTA Pure 25 using Superdex 200 10/300 GL.

\subsection{Electrophoresis}

It was noted that there were 6 protein bands (track A) for the crude extracted in polyacrylamide gel with an absence of denaturation materials of protein SDS, while appeared one protein band (track B) for enzyme after gel filtration, which means a high purity of enzyme as well as enhancing the results of gel filtration step as shown in Figure 2, seeing that [19] had gotten a one protein band represented the pure enzyme from Paecilomyces variotii.
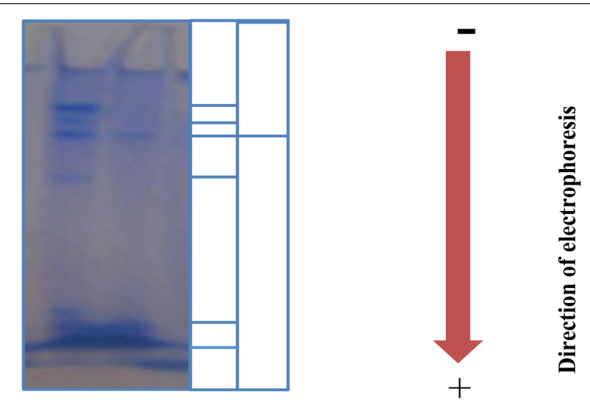

$\begin{array}{llll}\mathbf{A} & \mathbf{B} & \mathbf{A} & \mathbf{B}\end{array}$

Figure 2: Determination of tannase purity by electrophoresis in polyacrylamide gel without SDS, A: crude extracted; B: pure enzyme after gel filtration.

\subsection{Characterization of Enzyme}

\subsubsection{Molecular Weight}

Estimate the molecular weight for tannase by SDS-PAGE in the gel of a polyacrylamide using standard proteins as shown in Figure 3, that explains the relationship between logarithm the molecular weight of standard protein and relative movement of the protein itself, which shows that the molecular weight of tannase reached to $95.49 \mathrm{KDa}$.

Figure 4 explains the process of electrophoresis in polyacrylamide gel with SDS for standard proteins and pure enzyme, the results were different between researchers, it agreed with the findings of [20] that the molecular weight for tannase product from Aspergillus niger reached to $89.9 \mathrm{KDa}$ estimated in an SDS-PAGE, while molecular weight was $80 \mathrm{KDa}$ for tannase product from Aspergillus niger in SDS-PAGE [16].

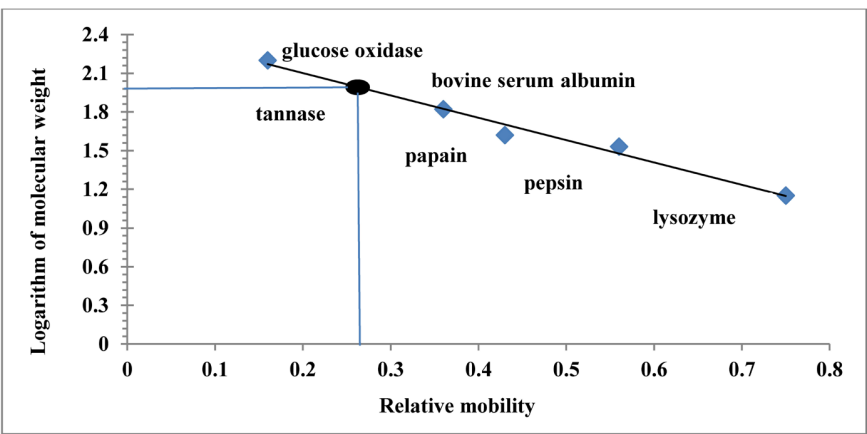

Figure 3: Standard curve to determine the molecular weight of tannase produce from Aspergillus niger $\left(\mathrm{A}_{13}\right)$ by SDS-PAGE.

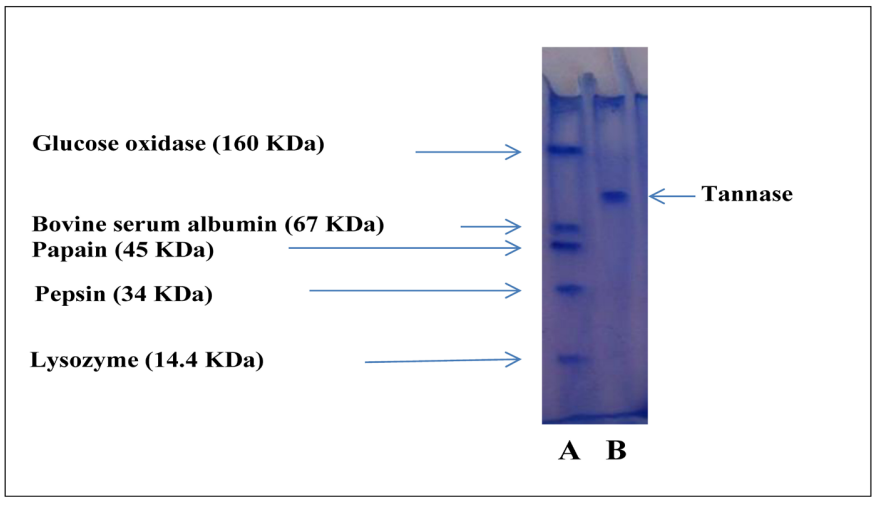

Figure 4: Electrophoresis with SDS in polyacrylamide gel, A: standard proteins; B: pure tannase. 


\subsubsection{Optimum pH for Activity and Stability}

Appeared from the results in Figure 5 that the optimum $\mathrm{pH}$ for the enzyme activity is 5 with enzymatic activity reached 525.2 (unit $/ \mathrm{ml}$ )), the results of the current study be in conformity with [21] that the optimum $\mathrm{pH}$ for tannase activity which produced from Aspergillus tamarii is 5 , also [22] noted that the optimum $\mathrm{pH}$ of the tannase activity was 5, as well as [23] clarify that the optimum $\mathrm{pH}$ of the tannase activity for free and restricted enzyme were 5 and 5.5 respectively, as referred [24] that the optimum $\mathrm{pH}$ for tannase activity was 5.5, while the results of the optimum $\mathrm{pH}$ for tannase stability produced from the local isolation Aspergillus niger $\left(\mathrm{A}_{13}\right)$ ranged between (3-6) as shown in Figure 6 where the enzyme had kept most of its activity for an 2 hours of incubation, while observed decreasing in $\mathrm{pH}$ at the values of $8,8.5$ and 9 where the remaining activity was 15,20 and $25 \%$ respectively, this decline is attributed to the influence of the $\mathrm{pH}$ in change the secondary and tertiary structure of the enzyme molecule and change the form of active site [25]. The results were similar to the findings of many researchers, so [22] pointed out that the optimum $\mathrm{pH}$ fort tannase produced of fungi ranged between (4.5-6) also clarify [24] that the optimum $\mathrm{pH}$ for tannase stability ranged between (3-6), either [26], explained that the optimum $\mathrm{pH}$ is 7.4 for tannase stability.

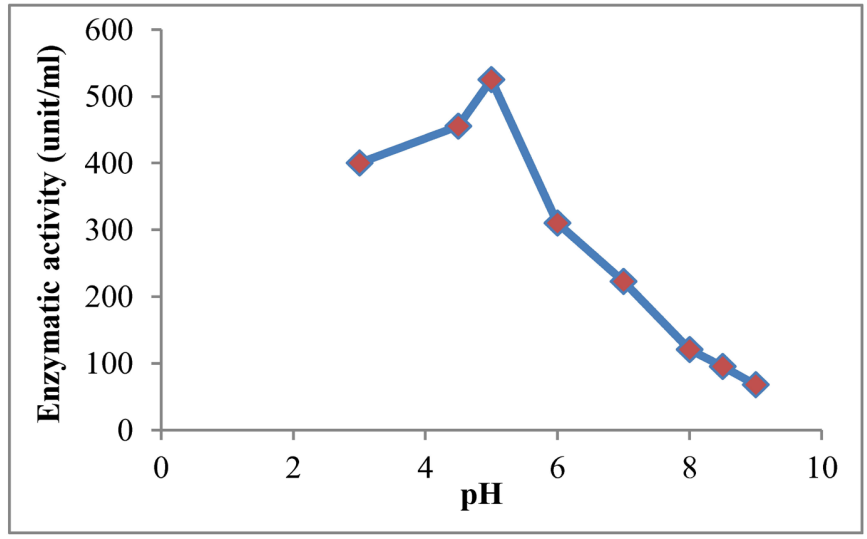

Figure 5: Optimum $\mathrm{pH}$ for tannase activity.

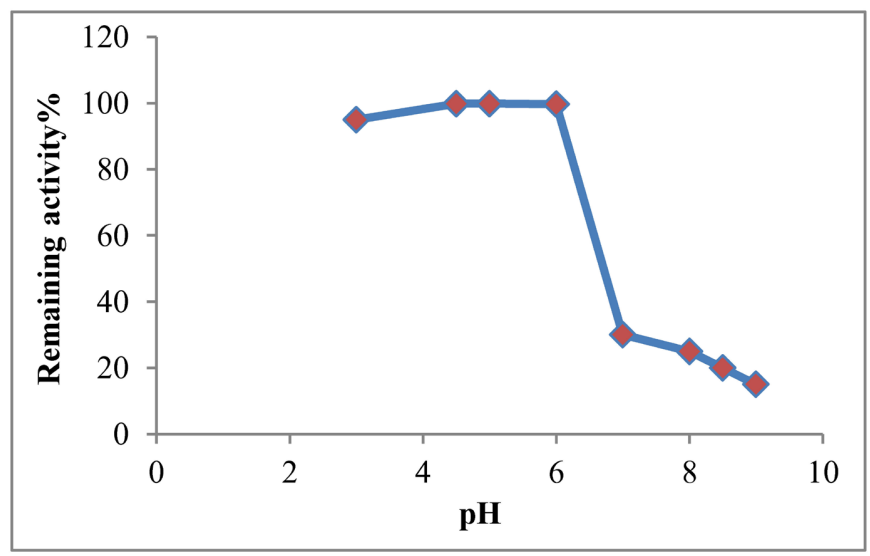

Figure 6: Optimum $\mathrm{pH}$ for tannase stability.

\subsubsection{The Optimum Temperature for Activity and Stability}

Observe from Figure 7 increasing the enzymatic activity with increasing the temperature until reached to its maximum of 520.5 (unit $/ \mathrm{ml}$ ) at a temperature of $35^{\circ} \mathrm{C}$, then decrease gradually to 250 (unit $/ \mathrm{ml}$ ) at a temperature of $50^{\circ} \mathrm{C}$ and continued to decline until reaching to 25.7 (unit $/ \mathrm{ml}$ ) at a temperature of $80^{\circ} \mathrm{C}$. The result has agreed with the result of [22] in determining the optimum temperature of tannase activity which was $35^{\circ} \mathrm{C}$, while noted [24] through the study of the optimum temperature of tannase activity was $60^{\circ} \mathrm{C}$, as well as determined [27] that optimum temperature of pure tannase from Aspergillus tamarii was $30^{\circ} \mathrm{C}$ for the free enzyme and $45^{\circ} \mathrm{C}$ for the restricted enzyme. Tannase was founded thermally stable in a range between $(30-50)^{\circ} \mathrm{C}$ as kept of its fully activity when incubation at these grades of temperature for 60 minutes, then lowered the activity rapidly with rising temperature even lost its full activity at $90^{\circ} \mathrm{C}$, while an enzyme kept about $50 \%$ and $38.4 \%$ at a temperature of $60^{\circ} \mathrm{C}$ and $70^{\circ} \mathrm{C}$ respectively as clarified in Figure 8 . The results were similar to findings of other researchers where reach [22] to determine the optimum temperature for enzyme stability, which ranged between $(25-45)^{\circ} \mathrm{C}$, as well as [24] found that tannase was thermally stable at temperatures of $(40-60)^{\circ} \mathrm{C}$, as mentioned [27] that pure tannase from Aspergillus tamarii with its forms free and restricted enzyme was kept of its activity at temperatures ranging from $(30-45)^{\circ} \mathrm{C}$.

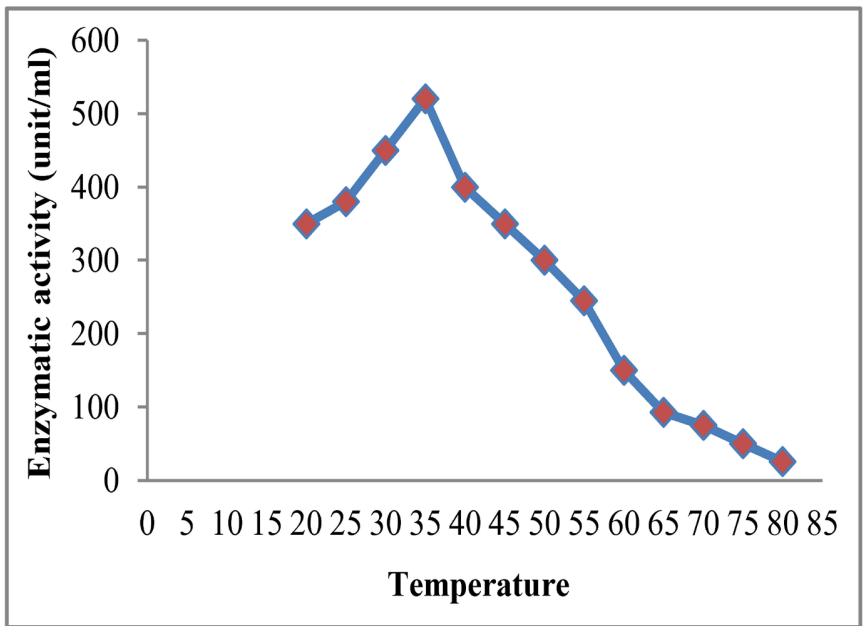

Figure 7: The optimum temperature for tannase activity.

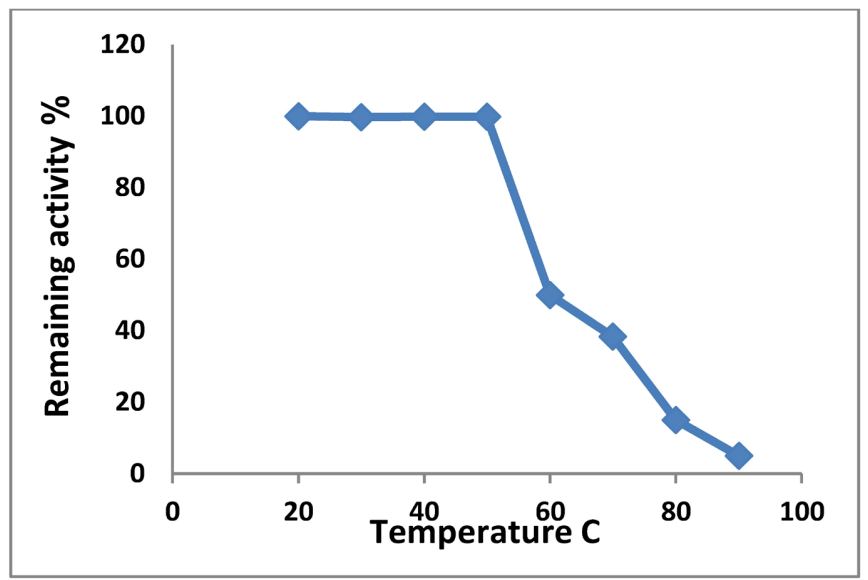

Figure 8: The optimum temperature for tannase stability.

\subsubsection{Effect of Metal Ions on Enzyme Activity}

The results of tannase treated with metal ions in Table 2 showed that the tannase was increased when treated with $1 \mathrm{mM}$ of $\mathrm{MgCl}_{2}$ and $\mathrm{KCl}$ 
while $\mathrm{Zn}$ and $\mathrm{Ca}$ slightly decreased of tannase activity at the same concentration. Some metal ions bind to the tannase and alter the enzymatic activity by stabilization or destabilization of the enzyme's conformation [28]. Furthermore, $\mathrm{Cu}, \mathrm{Fe}$, and $\mathrm{Hg}$ decreased in tannase activity occurred after incubation with 1 and $5 \mathrm{mM}$. The inhibition of tannase activity by these ions may indicate the presence of - $\mathrm{SH}$ group in the active site of the enzyme leading to oxidize theme moreover it may form a complex with the enzyme which prevents it from binding to the substrate and form the product. These results agree with [27] who showed the $\mathrm{Mg}$ ion was considered as activated for the enzyme, but $\mathrm{Hg}, \mathrm{Ca}, \mathrm{Fe}, \mathrm{Zn}$ and $\mathrm{Cu}$ were an inhibitor of tannase activity.

Table 2: Effect of metal ions on tannase activity produces from Aspergillus niger $\left(\mathrm{A}_{13}\right)$.

\begin{tabular}{ccc} 
Metal Salts & Concentration (Mm) & Remaining activity (\%) \\
Control & 0 & 100 \\
$\mathrm{MgCl}_{2}$ & 1 & 106 \\
& 5 & 100.51 \\
$\mathrm{HgCl}_{2}$ & 1 & 25.12 \\
& 5 & 22.32 \\
$\mathrm{FeSO}_{4}$ & 1 & 30.02 \\
& 5 & 28.04 \\
$\mathrm{ZnSO}_{4} \cdot 7 \mathrm{H}_{2} \mathrm{O}$ & 1 & 92.82 \\
& 5 & 87.3 \\
$\mathrm{KCl}$ & 1 & 100.45 \\
& 5 & 99.8 \\
$\mathrm{CuCl}_{2} \cdot 2 \mathrm{H}_{2} \mathrm{O}$ & 1 & 32.16 \\
& 5 & 30.71 \\
$\left(\mathrm{NH}_{4}\right)_{2} \mathrm{SO}_{4}$ & 1 & 73.24 \\
& 5 & 71.30 \\
$\mathrm{CaCl}_{2}$ & 55.36 \\
& 5 & 70.1 \\
\hline
\end{tabular}

\section{CONCLUSION}

In conclusion of the current study, Aspergillus niger a local isolate was found to be able to secrete tannase by SSF using wheat bran agroindustrial waste as a substrate for the production of this enzyme high industrial relevance, especially for the food industry. Tannase was purified from culture supernatant by ammonium sulfate, dialysis and gel filtration with AKTA pure a new technique, However, both the purification and the characterization of the enzyme are necessary to determine the commercial viability of the enzyme and possible application for industrial purposes, such as juice, tea, cosmetic, etc.

\section{ACKNOWLEDGMENT}

Many thanks to the Staff of Biotechnology Laboratory, Department of Food Science, College of Agriculture, University of Basrah, for the financial support of this study.

\section{REFERENCES}

1. Girdhari S, Peshwe S. Isolation and Screening of Tannase producing fungi. International Journal of Current Microbiology and Applied Sciences 2015; 4:765-774.

2. Kumari M, Jani S. Tannins: Antinutrient with positive effect to Manage diabetes. Journal of Recent Sciences 2012; 1:70-73.

3. Aguilar-Zárate P, Cruz-Hernández M, Montanez J, Belmares-Cerda R. Aguilar C. Bacterial Tannases: Poduction, Properties and Applications Tanasas bacterianas: Produccion, Propiedadesy Aplicacioness. Revista Mexicana de Ingeniería Química 2014; 13:63-74.

4. Gemede HF, Ratta N. Antinutritional factors in plant foods: potential health benefits and adverse effect. International Journal of Nutrition and Food Sciences 2014; 3:284-289.

5. Abd El Tawab AM, Khattab MSA. Utilization of polyethylene glycol and tannase enzyme to reduce the negative effect of tannins on digestibility, milk production and animal performance. Asian Journal of Animal and Veterinary Advances 2018; 13:201-209.

6. Mcgiinnis MR. 1980. Laboratory handbook of medical mycology. New York: Academic Press, Inc.

7. Pitt JI, Hocking AD. Fungi and food spoilage: 3rd Edition, Springer US; 2009; XV,519.

8. Al-Mraai STY, Al-Fekaiki DF, Al-Manhel AJA. Study the optimal conditions for the production of tannase from local Aspergillus niger by solid state fermentation. Misan Journal of Academic Studies 2018, in press.

9. Sharma NK, Beniwal V, Kumar N, Kumar S, Pathera AK, Ray A. Production of tannase under solid state fermentation and its application in detannification of guava juice. Preparative Biochemistry and Biotechnology 2014; 44:281-290.

10. Mondal K, Banerjee D, Jana M, Pati B. Colorimetric assay method for determination of the tannin acyl hydrolase (EC 3.1.1.20) activity. Analytical Biochemistry 2001; 295:168-171.

11. Lowry OH, Rosobrough N, Far AL, Randall RJ. Protein measurement with Folin phenol reagent. Journal of Biological Chemistry 1951; 193:265-275.

12. Laemmli UK. Cleavage of structural proteins during the assembly of the head of bacteriophage T4. Nature Publishing Group 1970; 227:680685 .

13. Garfin DE. 1990. Purification procedures electrophoretic methods. In: Murray ED, Dentscher PJ, editors. Methods in Enzymology. New York: Academic Press 425-441.

14. Liu TP, Porto TS, Moreira KA, Takaki GM, Brandão-Costa R, Herculano PN, Porto AL. Tannase production by Aspergillus spp. UCP1284 using cashew bagasse under solid state fermentation. African Journal of Microbiology Research 2016; 10:565-571.

15. Cavalcanti RMF, de Oliveira Ornela PH, Jorge JA, Souza LH. Screening, Selection and Optimization of the Culture Conditions for Tannase Production by Endophytic Fungi Isolated from Caatinga. Journal of Applied Biology \& Biotechnology 2017; 5:001-009.

16. Philip DC, Lavanya B, Latha S. Purification of tannase from Aspergillus niger under Solid State fermentation. World Journal of Pharmacy and Pharmaceutical Sciences 2015; 4:993-1001.

17. Nandi S, Chatterjee A. Extraction, partial purification and application of tannase from Aspergillus niger MTCC 2425. International Journal of Food Science and Nutrition 2016; 1:20-23.

18. Anitha A, Arunkumar D. Extraction, Partial purification and characterization of tannase enzyme from Mucor sp. Nehru E-Journal 2013; 1:25-29.

19. Mahendran B, Raman N, Kim DJ. Purification and characterization of tannase from Paecilomyces variotii: hydrolysis of tannic acid using immobilized tannase. Applied Microbiology and Biotechnology 2006; 70:444-450.

20. Viswanath V, Leo VV, Prabha, SS, Prabhakumari C, Potty V, Jisha M. Biosynthesis of tannase from cashew testa using Aspergillus niger MTCC5889 by solid state fermentation. Journal of Food Science and Technology 2015; 52:7433-7440.

21. Enemuor SC, Odibo FJC. Partial purification and characterization of Aspergillus tamarii IMI388810 (B) tannin acyl hydrolase. Archives of 
Applied Science Research 2010; 2:290-299.

22. Wagh SA. Bioconversion of tannic acid to gallic acid by using fungal tannase. Ph.D. thesis, CSIR-National Chemical Laboratory, Pune, India; 2010.

23. El-Tanash A, Sherief A, Nour A. Catalytic properties of immobilized tannase produced from Aspergillus aculeatus compared with the free enzyme. Brazilian Journal of Chemical Engineering 2011; 28:381-391.

24. Ordoñez R, Colombo I, Alberto M, Isla M. Production of tannase from wood-degrading fungus using as substrate plant residues: purification and characterization. World Journal of Microbiology and Biotechnology 2011; 27:2325-2333.

25. Whitaker JR. 1972. Principles of enzymology for the food science. New York, USA: Marcel Dekker. Inc.

26. Bagga J, Pramanik SK, Pandey V. Production and Purification of Tannase from Aspergillus aculeatus Using Plant Derived Raw Tannin.
International Journal of Scientific Engineering and Technology 2015; 2:50-55.

27. da Costa AM, Kadowaki MK Minozzo MC, de Souza CGM, Boer CG, Bracht A, Peralta RM. Production, purification and characterization of tannase from Aspergillus tamarii. African Journal of Biotechnology 2012; 11:391-398.

28. Yao J, Guo GS, Ren GH, Liu YH. Production, characterization and application of tannase. Journal of Molecular Catalysis B: Enzymatic 2014; 101:137-147.

How to cite this article:

Al-Mraai STY, Al-Fekaiki DF, Abd Al-Manhel AJ. Purification and characterization of tannase from the local isolate of Aspergillus niger. $\mathrm{J}$ App Biol Biotech. 2019;7(01):029-034. DOI: 10.7324/JABB.2019.70106 